\title{
Judicial Activism in Pakistan is Challenging for Foreign Investor in the Context of China and Pakistan Economic Corridor
}

\author{
Li Youxing ${ }^{1} \quad$ Muhammad Farhan Qureshi ${ }^{2}$ \\ 1 .Professor of law, Guanghua Law School, Zhejiang University, Hangzhou,Zhejiang Province, 310008 China \\ 2. Doctoral Candidate in Law,Guanghua Law School,Zhejiang Univesity,Hangzhou. \\ Zhejiang Province 310008 China
}

\begin{abstract}
The judiciary has an important role in Pakistan. If the judicial system of any state provides appropriate law and justice, it would not only benefit local investors, but also provide a favorable environment for foreign investors to enhance their business. The support of the judiciary system is crucial for foreign investors in order to enhance FDI. In the past few years foreign investors were facing challenges by the courts in Pakistan. Due to judicial activism not only Pakistan being a host state had to experience failure in investment projects, but also the foreign investors had to become a victim of massive loss.In the constitution of Pakistan the courts have the power to take action against any case in the interest of the public. Suo moto is a constitutional power and judiciary have the right to use this power in any case.China is initiating a huge investment in Pakistan, which will not only provide great scope to the investors in growing their businesses but also will promote job opportunities, technology transfer,economics and prosperity of Pakistan. The judiciary system of Pakistan is likely to impose great challenges to the Chinese investors.It has been observed in the past that the judiciary in Pakistan had played a role in creating issues in the development of foreign investment leading to termination of the investment agreement.Moreover in some cases foreign investors were compelled to leave the country. Due to judicial activism privatization of Steel mill had been halted which became a burden to the Government of Pakistan. The foreign investment in Rental Power Project had also been terminated due to judicial activism. Chinese investment in Orange train is a recent example of judicial activism in Pakistan, which led to huge loss to the Chinese investors on account of halting of its construction after the agreement.
\end{abstract}

Keywords. Judiciary,Foreign investor protection,Judicial Activism,CPEC

DOI: $10.7176 / \mathrm{JLPG} / 95-13$

Publication date:March $31^{\text {st }} 2020$

\section{Introduction}

The investment of China in Pakistan will bring prosperity, not only to the country but also other parts of the world. CPEC will not only flourish and strength Pakistan's economy, but also boost development in the neighbouring countries including Iran and India. CPEC is a part of one belt one road. Foreign investors not only have to follow their native investment law ,but also abide by the host state's which sometimes create a deadlock situation for the investment to grow. Chinese investors have to face challenges and dangers of the judicial system of Pakistan. The Supreme and High courts of Pakistan have constitutional power to stop or terminate foreign investment if it is against the public interest. The graph of FDI has decreased due to judicial activism in Pakistan. Pursuing Sou Moto as a conventional affair gives rise to severe reservations about its legality, value, usefulness and its legitimacy of treaties and acknowledgements enacted by the government of Pakistan. The authority to improvise the constitutional rights is with the Superior Courts. ${ }^{1}$ On the other hand the situations in which there are clear legal provisions, the courts are obliged to stick to exact meaning of this kind of rules stringently and to perform as law's court. Though compulsory application of law is guaranteed by the philosophy of court of law, but in every situation justice does not prevail as the essential outcome. ${ }^{2}$ Contrary to judicial activism in which the courts work as justice courts instead of courts of law as well as judges have a huge power to explain the constitution for the regulation of society's justice. As illustrated by Black's Law, the judicial activism is y law-making's philosophy in which judges are able to share their prospects about public policy, to council their decisions. ${ }^{3}$ There is no doubt that the provisions of the constitution are unambiguous that Supreme Court or High court's jurisdiction of judicial review is confined to breaching of basic rights. ${ }^{4}$ For the first time the Supreme Court took account of the issue of first legislation of public interest in the case of Benazir Bhutto against the government of Pakistan (1988) ${ }^{5}$. In the cases where there is violation of basic rights, the jurisdiction of the High court as Supreme Court could only be applied, but this might be limited to the fundamental rights $\mathrm{f}^{n}$ gfof the individual or a group of people whose rights have

${ }^{1}$ Golden and mischief rules for the interpretation of statutes

${ }^{2}$ Literal rule for interpretation of statutes

${ }^{3}$ Court follows the application of strict rules of law

${ }^{4} 4$ Andrew P. Napolitano: Lies the Government Told You: Myth, Power, and Deception in American History (7th edn, Nashville Tennessee Thomas Nelson Inc 1999)

${ }^{5}$ Benazir Bhutto v Federation of Pakistan (1988) PLD SC 416 
been violated. Every authentic person who has been affected and whose fundamental rights have been violated is allowed by the court to approach for justice to the court for the support of the people who could not seek justice due to several reasons. In this paper the challenges and issues faced by foreign investors due to judicial activism in Pakistan have been highlighted based on the evidence and cases in the recent past.

\section{History of judicial Activism}

Judicial activism should not be considered a new scenario as its history extends through the many decades. In most of the jurisdictions, different things have played important roles in contributing to the uprising of it that includes state organs; executives and legislators. It finds and reinforces its history in several events like that of violation of the law and constitution, malfunctions, corruption as well as nepotism and non-compliance. ${ }^{1}$ One of the great advocates of judicial activism in India, Former Indian Supreme Court Justice V.R. Krishna Layer once said: "Judicial activism receives its biggest award when its authority removes tears from some eyes." In 1607-1608, in Foundation of judicial activism, there had been disagreement between the king of England of that time, King James and the CJ of England, justice Coke, on authorizing the transferring of a case to the king. CJ Coke said that the law is superior, paying little respect to whether the ruler isn't under man, be that as it may he will be under the law and God. In like way, King James couldn't ensure the capacity to constrain evaluates on import and admission since CJ Coke articulated it unlawful and attested that the parliament was the primary pro to take the decisions of driving charges. ${ }^{2}$

\section{History of Judicial Activism in Pakistan}

Benazir Bhutto, president of the Pakistan People's Party, constituted the first case of litigation of public interest, in which the clauses of the 1962 Political Parties Act were contested. Even though the petition had been submitted, according to Article 184, paragraph 3 of Constitution, in the form of a dispute in the public interest, ${ }^{3}$ but has been harshly criticized for being contrary to the specified nature of the public interest law, intended only meant for the poor, destitute and unprivileged class. Kind of company. ${ }^{4}$ Professor Menski complained that people with money and power in Pakistan could easily use the techniques of litigation of public interest for their political interests. A long standing practice of the courts should be managed with self-control and, for the most denied authority, not granted by the Constitution. ${ }^{5}$ Throughout the literature, under the light of the current judicial system of Pakistan, it has been evident that the judiciary comprises of the Supreme Court, provincial high courts, and other smaller courts exercising civil and criminal authoritative decision-making practices. The Supreme Court is considered to be the summit court in Pakistan's judicial pyramid, the ultimate mediator of legal and constitutional disagreements $^{6}$. The Supreme Court of Pakistan entails of a Chief Justice, further limiting its extent to hire at most 16 other Judges under the direction of the President. An individual having a five years' experience as a Judge of a High Court or 15 years' experience in hand as a supporter (advocate) of a High Court is qualified to be selected as a Judge of the Supreme Court. The chief justice of the Supreme Court is selected under the guidance of the President; the additional Supreme Court judges are employed by the President afterward having discussion sessions with the chief justice. High courts have the inventive and appellate judicial legislation. Through reviewing the history of Pakistan, the very first jurisdiction was placed in 2007, the sedentary Chief Justice was deferred by the government on controls of exploitation of power. The Chief Justice was provided with an option to resign; however, on the refusal of the opportunity concerning the judicial, the chief of justice was forcefully removed from the position under the series of the allegation filled against him. The allegation included the violation of the laws including the judicial decorum, bribery, looking for favors from the foreign executives and disobedient with senior attorneys. In retort, the Chief Justice, Iftikhar Muhammad Chaudhry, certain to encounter his postponement in the Supreme Court of Pakistan. The Chief Justice's deferment was trailed by extensive complaints on the share of the legal communal, civil civilization, and nearly every political parties in the country. The complaints positioned around not only on the absence of rationality of the claims in contradiction of the Chief Justice but similarly on the inquiry of whether the President possesses the significant influence to dismiss the Chief Justice under any settings?

Pakistan is seen to be facing the issues related to the judiciary especially from after the privatization issue of Pakistan Steel in 2006. The Expansion related to the fundamental rights and the public interest litigation provided

\footnotetext{
${ }^{1}$ Khadim Hussain Qaiser, 'Public Interest Litigation' Additional Advocate General Punjab paper presented in International Judicial Conference organized by Pakistan Law Commission at Supreme Court Building Islamabad Pakistan ( Re produced from original)

2 Coke, Sir Edward (1552-1634); the forum at the online library of liberty, A project of library fund Inc $<$ http://oll.libertyfund.org/index.php?option=com_content\&task=view\&id=226\&Itemid=270 $>$ accessed $2 / 11 / 17$

${ }^{3}$ Menski. W. and others (2000).Public Interest Litigation in Pakistan. Karachi:

${ }^{4}$ Menski. W. and others (2000).Public Interest Litigation in Pakistan. Karachi:

${ }^{5}$ State $v$ Zia ur Rahaman (1973) PLD SC 49

${ }^{6}$ Hussain, Faqir. The judicial system of Pakistan. Supreme Court of Pakistan, 2011.

${ }^{7}$ Awan, Mohammad Raheem. Judicial activism in Pakistan in commercial and constitutional matters: Let justice be done though the heavens fall. Journal of International Criminal Justice Research Volume 1 (2014).
} 
a broad scope for the judicial interventions in the different matters. The use of the different judicial powers particularly the 'suo moto' action is considered to be very important in the different matters including the social, economic or the political affairs that are related to the FDI.It is needed that the different treaties and the agreements must be signed by the government. The judiciary in Pakistan has been affected by the different governments of the dictatorship and it is seen that several time the military governments have asked the judges to take the oaths again under PCO. They were not allowed to act collectively or to resist to any institution, taking the different measures that might provide the independence to the judiciary ${ }^{1}$.

The act of the Judicial, in where the judges declare themselves to distribute justice among the society has been highly affected by the regimes of the political changing situation and considered to be a significant discouraging influence in Pakistan. It is an exclusive and idiosyncratic component of Pakistan's existing judicial past which treasures its origins in accusations of exploitation, enticement, and inducements (bribe) at the same time as implementing venture agreements and bestowing multibillions development projects to the off-shores companies. The assertion of unethical performs on politicians, senior officeholders, and stockholders have delivered a chance to the Supreme Court of Pakistan to increase the possibility of Public Interest Litigation (PIL) and yield particular issues unswervingly in the SCP in its innovative or suo moto authority ${ }^{2}$. The judges provided a position in the SCP has right to take notification of sort of incidence happens in the certain circumstances by their own will, without providing any kind of formal pledge to highpoint the disagreement or declare defilement of legal rights. The exclusive authority permitted the 'suo moto' (action on court's own motion) dominion. In the last ten year of the Pakistan Supreme Court history, the enforcement of constitutional fundamental rights ("CFR") and PIL have prolonged the range of suo moto authority to overseas venture (foreign direct investment) and contractual problems. The SCP has been contradicting various commercial agreements implemented by the GOP and further Governmental individuals ${ }^{3}$. Accusations produced by the people for non-transparency of the constitutional regime, corruption and bribes from overseas stockholders to amend privileged investment agreements and grant high investment developments projects in the indulgence of the governmental officials have unbolted the entrance of judicial involvement. The termination of denationalization of steel mills, speculation contracts for power generation fall under the category of the 'Rental Power' and investigation of gold and copper discoveries in Reko Diq entitled as the 'Reko Diq mines' are archetypal instances of judicial involvement in Pakistan in marketable and settlement problems ${ }^{4}$. The extent of the involvement by the judicial officials in Pakistan can be determined from the influences of the various determinants on the crucial substances, wherein the SCP dismissed the former prime minister holding the position of the country by condemning him for disrespect of court. The SCP correspondingly distributed additional disapproval of court announcement to the subsequent prime minister persuasive him to transcribe a memo to Swiss establishments for resurrecting exploitation and dishonesty cases in contradiction of former president of Pakistan ${ }^{5}$. To evade ineligibility of additional Prime Minister Government accomplished to become approved Contempt of Court Act 2012 after Congress. However, the following act as an attempt to restrain controls of SCP over legislature likewise continued as an unsuccessful attempt after SCP collides down with whispered doubtful legislation by announcing it unauthorized and illegitimate law. The particular risky implementation of judicial supremacy under legitimate power 'suo moto' validates the ability of the superior judiciary to reconsider to some extent any sort of the contract, settlement, and portion of legislation to regulate its legitimacy, constitutionality, and rationality. One of the other essential dimension of judicial involvement in Pakistan is the application of 'suo moto' through the High Courts, notwithstanding with the enormous characterization of suo moto or alike power status as the non-availability of the regimes for the High Courts. Over the course of the history, it has been contended that the following developing inclination of judicial engagement is improbable to provide any ease to foreign investors and advances queries as to the sacredness of contracts and agreements employed by the $\mathrm{GOP}^{6}$.

The impacts of the different powers matters that are related to the FDI and the sanctity of the different investments agreements and the treaties by the Government of Pakistan, the different issues related to it are often considered by the judiciary. By considering the philosophy related to the judicial activism for the different countries are seen to be administered by the constitution. By considering the history of Pakistan one might provide the facts that different judges might not provide the development of the judicial institutions. They have not responded as a whole institution as it could be a threat to the integrity of the judiciary ${ }^{7}$. During 2007 it was seen

${ }^{1}$ Sial, Abdul Quddoos. "Implications of Assorted Constitutional Principles on Administration of Justice in Pakistan." Pakistan Journal of Social Sciences (PJSS) 31, no. 2 (2011): 227-239.

${ }^{2}$ Hussain, Faqir. The judicial system of Pakistan.Supreme Court of Pakistan, 2011.

${ }^{3}$ Tarar, Maliha Gull, and Venkat Pulla. "Patriarchy, gender violence and poverty amongst Pakistani women: A social work inquiry." International Journal of Social Work and Human Services Practice 2, no. 2 (2014): 56-63.

${ }^{4}$ Khan, Ahmad, Tanveer.Judicial System of Pakistan. Available at: http://www.pja.gov.pk/system/files/Judicial_System_of_Pakistan.pdf

${ }^{5}$ Sornarajah, Muthucumara swamy. "Power and Justice: Third World resistance in international law." SYBIL 10 (2006): 19.

${ }^{6}$ Gazdar, Haris. "Judicial activism vs democratic consolidation in Pakistan." Economic and Political Weekly 44, no. 32 (2009): 8-14.

${ }^{7}$ Tarar, Maliha Gull, and Venkat Pulla. "Patriarchy, gender violence and poverty amongst Pakistani women: A social work inquiry." International Journal of Social Work and Human Services Practice 2, no. 2 (2014): 56-63. 
that for the first time in the history of Pakistan the Chief Justice was suspended by the government due to abusing the powers. Chief Justice was provided with the option to resign but he refused and was removed forcefully by the imposing different charges on him such as the charges of corruption, violating the different rules and taking the favors. He challenged his suspension and it took the form of a huge campaign for his restoration that was supported by the large number of lawyers, civil society, and the different political parties. Different protests were seen to be centered on the thing that the allegations against Chief Justice were not valid and also whether the President had the authority to take the decision alone for the suspension of Chief Justice ${ }^{1}$.

Until the year 2012 , the different conection between the judicial system and the different authorities were seen to be reaching stable conditions. The sitting Parliament completed the tenure and the NRO story took the turn. The Supreme Court ordered to remove the Chairman NAB due to the failure for the assistance of the NRO case in the court and also the inappropriate nomination of the Prosecutor General providing the selection of the neutral person as the Chairman NAB, the person who would be responsible for carrying out the different responsibilities in a sensible way, who will be able to provide the cases in front of the government for making the political survival ${ }^{2}$. On the other hand, the frustration with the incapability to make the government understand the different things related to the corruption cases is important. The Supreme Court has made some important decisions in the history such as the disqualification of the Head of state. The decisions made by the court are however respected by the different political parties despite the fact that the decision was not in their favor ${ }^{3}$. Judicial activism is a concept which refers towards the rulings made by courts on innovative, modern and relevant interpretation of the law which are already been existent. The concept is usually applicable in the under developed countries where the distribution of power is not clearly defined and political issues as well as crisis is a normal thing ${ }^{4}$. Pakistan being a Third World developing nation, has faced judicial activism many times during different eras and governments. The history of judicial activism in Pakistan dates back to 1980's when the form of government changed and long term dictatorship of General Zia ul Haq had ended. After that the Supreme Court started intervening in the matters of the state. Before that, many cases like that of Molvi Tamizuddin Case, Nusrat Bhutto Case, etc had witnessed the bowing of judiciary in favour of the Executive under the Doctrine of Necessity. The year 1996 marks the major landmarks in the history of judicial activism in Pakistan when the Supreme Court intervened and exercised its power against the legislature ${ }^{5}$. After that it has become a norm in Pakistan. Even in recent era, the judicial activism in on rise under the leadership of Justice Mian Saqib Nisar, the Chief Justice of Pakistan.

In recent days the Chief Justice of Pakistan has taken sou moto notice of several of issues being happening in the country. Other than that he is also quite actively responding to the petitions signed in the Supreme Court. He has taken action on various cases in recent months like that of Zainab Rape Case in Kasur, Asma Murder Case in Mardan, Naqeebullah Mehsood Murder Case in Karachi, etc ${ }^{6}$. Other than that he also takes notice in health and education sector. Recently he ordered all the private medical colleges of the country to reimburse the extra amount of fee charged by them to the students. He visited Bolan Medical College in Quetta and also took notice of lack of adequate facilities in the hospital. He has also visited various hospitals across the country ${ }^{7}$. Moreover he summoned the current Chief Minister of Balochistan which is the main province in CPEC, along with two of the former Chief Ministers of current term, in order to ask them for the lack of development in the province . $^{8}$

Other than these social issues the Supreme Court is also interfering in the ongoing political issues of the country. The historic decision made by the Supreme Court bench which dismissed the sitting Prime Minister Mr. Nawaz Shareef in light of Article 62 and 63 of the Constitution of Islamic Republic of Pakistan. On 13 ${ }^{\text {th }}$ April the, Supreme Court declared the dismissal of former Prime Minister, effective for lifetime ${ }^{9}$. This marks a major milestone of the judicial activism in Pakistan. The analysts have suggested that this action would have negative impacts on CPEC as the political instability is never welcomed by any kind of investors throughout the world, not only in the case of CPEC but overall trend suggests the similar kind of ideas. This kind of judicial activism can also impact the major projects going on in the country like that of CPEC. Mr. Nisar has recently said that he would halt the construction of Orange Line Train in Lahore if the education and health sector of the country keeps on getting ignored. As the Orange Line Train in Lahore is part of CPEC, it would not wrong to say that the judicial activism in Pakistan is now taking the CPEC under its jurisdiction. He also visited the construction site in Lahore and talked to the media after the visit ${ }^{10}$. It has been argued by various analysts that if he continues to exercise

\footnotetext{
${ }^{1}$ Abbasi, Imran Naeem. "Protest of doctors: a basic human right or an ethical dilemma." BMC medical ethics 15, no. 1 (2014): 24

${ }^{2}$ Newberg, Paula R. "Governing Pakistan." Asian Affairs: An American Review 41, no. 4 (2014): 159-171.

${ }^{3}$ Abbasi, Imran Naeem. "Protest of doctors: a basic human right or an ethical dilemma." BMC medical ethics 15, no. 1 (2014): 24

${ }^{4}$ Christopher Wolfe, Judicial activism, Rowman \& Littlefield

${ }^{5} \mathrm{http}: / /$ www.cssforum.com.pk/css-compulsory-subjects/essay/essays/74587-judicial-activism-pakistan.html

${ }^{6} \mathrm{https} / / /$ www.thenews.com.pk/print/275873-12-federal-secretaries-to-attend-njpc-meeting

${ }^{7} \mathrm{https}$ ///www.thenews.com.pk/latest/303569-cjp-nisar-hints-at-reviewing-pml-ns-tax-amnesty-scheme

${ }^{8}$ https://www.dawn.com/news/1386359

${ }^{9} \mathrm{https}: / /$ www.dawn.com/news/1401362

${ }^{10} \mathrm{https}$ ://en.dailypakistan.com.pk/pakistan/cjp-saqib-nisar-examines-ongoing-orange-line-train-project/
} 
judicial activism and starts impacting the CPEC and Chinese investment in Pakistan, then it would be a major issue for the progress as well as development of CPEC. The Chinese also share strong reservations on the ongoing political crisis in the country, in which the judiciary has become a major party against the government. The roles of Executive, Judiciary and Legislature have been clearly defined in the Constitution of Pakistan but still the issue persists. He also says that he will interfere in the governments proceeding related to CPEC as he wants the continuity of $\mathrm{CPEC}^{1}$. But the political pundits assess this statement as a threat to CPEC and Chinese investment rather than a support for it. These kinds of projects are to be dealt by the elected government and its representatives, not by the judges and judiciary. The current government has very cordial relations with their Chinese counterparts and the role of government representatives and machinery has been widely applauded by the Chinese officials in recent years ${ }^{2}$. In this kind of situation the undue influence made by the Supreme Court under the idea of judicial activism might leave negative impacts on the communication and development of CPEC. So the idea of judicial activism shall be discouraged in order to make a faster transition and development of CPEC, rather than encouraging the practice of judicial activism in Pakistan.

\section{Judicial activism and Constitutional and Institutional Role}

The period of former CJ of the Supreme Court Mr. Iftikhar Muhammad Chaudhry was characterized by significant progress in the authority of the SCP. This period in judicial history of Pakistan has also been stained by a great controversy since court has faced accusations of having participated in "judicial activism", has acted on political basis and abused the powers established by the constitutional mandate between the institutions of the state. This chapter demonstrates detailed analysis of the actions related to judicial review of the Court of Chaudhry, mentions the accusation of judicial activism is mainly unusual and critically blurred. ${ }^{3}$ The judicial activism 's concept is based distinctions between law as well as politics and politics and unable to provide a structure to properly analyze or evaluate the type of politics that Pakistan has recently going through. The role of the Supreme Court, like of any supreme court with legal and authoritative documents. ${ }^{4}$ An excellent case of this type of judicial review that involved essential people from the political authority is the implied RPP case ${ }^{5}$. The Judge got an unusual condition of caution of pollution claims and deliberate incident to the all-inclusive community treasury in the assertions to nineteen years rental impact wanders (RPP). The court asked for the NAB to start examinations against the administration serve being alluded to, Raja Pervaiz Ashraf and experts in administration of water and power in the wake of tuning in to the at first sight affirm of infractions. While the Court made sense of how to cross out the concurrences with the RPPs and guaranteed there turn of advantages for general society treasury, NAB examinations against the chose government the serve and distinctive specialists remained pending all through the residency of the past government , and Raja Pervaiz Ashraf ended up being even the Deputy Prime Minister on the prevention of the Prime Minister Gilani from the SCP. ${ }^{6}$

\section{Case of Pakistan steel mill}

The first big case came into light was the privatization of Pakistan steel mill in the year 2006, which was followed by high profile cases opposing administrators were dealt by the Supreme court of Pakistan many times The era was considered to be of judicial activism in Pakistan began with the PSM case, cancelled the \$362 million bid for the privatization of PSM was by the Supreme Court's larger bench. The decision taken by the SCP mentioned the amount of violations caused due to lapses, ${ }^{7}$ oversights, breaches and committees by the privatization committee and Cabinet Commission on Privatization ${ }^{8}$. The judgment took by the SCP was believed to save loss of 18 billions and RS 33.67 billion extra profit to the bidder. Although the savings in privatization were temporary and found to be a trivial saving after the announcement of the saving of RS 23 billion by the government in PSM while it was its first year of finance of newly developed government. ${ }^{9}$

In Daily Dawn Pakistan a report was published stating that, until $31^{\text {st }}$ Oct 2012 regardless of the bailout package of 14.6 billion by the federal government the obligatory debt of PSM has exceeded to100 billion in December 2013. ${ }^{10}$ Despite having Rs 7 million debt the PSM had managed to earn Rs 2.3 billion profit during

\footnotetext{
${ }^{1} \mathrm{https}: / /$ www.geo.tv/latest/179424-want-to-resolve-all-cpec-related-disputes-cjp

$2 \mathrm{https}$ //en.dailypakistan.com.pk/headline/no-stay-on-cpec-related-projects-cjp-orders-pakistani-courts/

${ }^{3}$ Iftikhar Muhammad Chaudhry served as the Chief Justice of Pakistan from 2005 to 2013.new paper

${ }^{4}$ See generally THE POLITICS \& JURISPRUDENCE OF THE CHAUDHRY COURT (Moeen H.

Cheema and IjazShafiGilani eds., 2014) [hereinafter POLITICS \& JURISPRUDENC

5 15See MateenHaider, NAB to probe Parvez Ashraf for illegally awarding RPP contract, DAWN (Apr. 14, 217, http://www.dawn.com/news/1175888

${ }^{6}$ In the matter of Alleged Corruption in Rental Power Plants etc., (2012) SCM (SC) 773.

${ }^{7} 17$ Wattan Party and others $v$ Federation of Pakistan and others [2006] SC, SCP Constitution Petition No. 9 of 2006 \& Civil Petition Nos. $345 \& 394$ Of 2006

${ }^{8}$ Some important cases were, Privatisation of steel mill case: construction of McDonald's restaurant in F/9 public park Islamabad case: pld

${ }^{9}$ Mohammad Kamran, 'Judicial activism SC's hallmark in 2006' Daily Time, 1/1/2018

${ }^{10}$ Report telecasted on Major Pakistani TV channels on 19th December 2017
} 
2007-08 which is quite noteworthy situation. ${ }^{1}$ with reference to the papers which claimed that there was a dropped down in the Pakistani steel's production to $6 \% 90$, previously which had been $92 \%$ in April 2008 another new government had been formed. The report also suggested that until October 2012 Rs 79 billion loss had been suffered by the PSM due to cancellation or annulment of its privatization by the SCP. Suo Motto notice had been taken by the SCP on account of huge corruption and irregularities and lapses in PSM. It can be clearly observed that the decision of SCP to annul the privatization of PSM caused massive losses which continued to increase regardless of savings claimed by the PSM.

\section{Foreign investor and Rental power case}

Another major case is the rental power RPP case ${ }^{2}$ which have the credit of having everlasting impacts on Pakistan's International, commercial and political domains. According to the most looked for judgment about RPP case, the SCP highlighted enormous corruption, lapses and bribes allegedly \$5 billion which led to it the invalidation of the RPP project. Subsequently all the agreements by the rental power were held illegal and invalid by the SCP. ${ }^{3} \mathrm{An}$ order was passed by the SCP for prompt criminal action against the project and compensation of the whole paid amount with interests. ${ }^{4}$ It was identified by the SCP that expanding the advance payment in to billions from $7 \%$ to $14 \%$ runs which was not acceptable without bidding, to make sure proper competition among the bidders and was not independent of illegalities from the government. RPPs were identified to be an absolute failure by the SCP and it was against the Article $9 \& 24$ of the constitution and said to be conflicted with the Section. ${ }^{5}$

The SCP held a disrespect of court and a notice was sent to the Chairman NAB and others. ${ }^{6}$ On 8/11/2012 an order was also passed by the SCP in opposition to RPPs named Barage Mounted Karkaya which is a Turkish firm restricting it from moving out of Pakistan unless all the payables and compensation had been cleared. Here it is worthwhile to mention that NAB had allowed karkay to sail out of the country without having to compensate the outstanding due amount. After identifying the situation the Chairman NAB was held responsible by the SCP if Karkay move out of Pakistan without recovery of the dues. 28 On $15^{\text {th }}$ January 2012 case was held and an order was passed by the SCP to the NAB authorities to arrest all the RPPs fraudulent irrespective of their positions and authority. The Prime minister of that time and other ${ }^{7}$ people were held responsible. It was further ordered by the SCP that chairman NAB will be responsible if anyone was able to leave the country with its respect. The RPPs decision is going to have a profound impact on International political and economic outcome.

\section{Chinese investor and orange train case}

The orange train line metro project is currently the topic of concern in the country. This is a major project by a Chinese company. The orang train project is the outcome of the agreement between Pakistan and China at the level of state. ${ }^{8}$ This is a living example of Pakistan's public interest litigation; in this case the civil society had filed a petition in LHC against its construction under Article 199 constitution of Pakistan. ${ }^{9}$ The high court ordered on $19 / 8 / 16$ confirming the stay order to stop the work. The high court gave verdict that the orange train routes would damage the heritage sites of Lahore. As stated the case of M.D Tahir agaisnt federation of Pakistan's case, under $199^{\text {th }}$ Article of the constitution an advocate protested against the legality, ownership and approval of the cost and spending on the president of Pakistan's tour to the USA and performance of Haj-i- Baitullah by the Prime Minister of Pakistan. The Lahore High Court looked upon the annoying and frivolous litigation with abominance and claimed that precious time of the court is halted for the heritable cases by attempting this act. It was also stated by the court that the aims of such petition are to boast the reputation of the petitioner in order to get the attention in the news and to threat and defame the Government/ Authorities; thus such attempts were strongly discouraged by the court. Further it was declared by the court that such rampant rights cannot be provided under umbrella of public interest regulations, to any person or group who attempt to file frivolous and trivial writs for personal gains and interests. ${ }^{10}$ Viewing the Khurram Khan v. Punjab Government's case, it was proclaimed by the High court that

\footnotetext{
1 Khaleeq Kiani, 'Steel Mills debt liability exceeds Rs82bn' Daily Dawn \& DawnPakistan.com10th November, 2012 http://dawn.com/2012/11/10/steel-mills-debt-liability-exceeds-rs82bn/accessed on 22/02/2018

${ }^{2} 22$ Human Rights Case No. 7734-G/2009 \& 1003-G/2010 (Alleged Corruption in Rental Power Plants) and other connected Human Rights Case No. 56712/2010 (Fraud in payment of Rental Power Plants detected by NEPRA). http://www.supremecourt.gov.pk/web/user_files/File/HRC7734-G_1003 GOF2009 [Alleged Corruption in Rental Power Plants]. pdf ${ }^{3}[2012]$ SCMR 773, Paragraph 83(3)

${ }^{4}$ The Supreme Court on Friday Declared Rental Power Projects (Rpps) As Illegal and also Ordered them to be Shut Down' Dawn news Report 30th March 2017.http://dawn.com/2012/03/30/rpps-declared-illegal-by-supreme-court/

${ }^{5}[2012]$ SCMR 773Paragraphs 78 and 79

${ }^{6}$ Order dated 15/09/2012 in implementation of RPPs case CMA No.4649 of 2012

${ }^{7}$ Summary of the order dated 18/11/2012 in Paragraph 2 of C.M.As.NOs.3685-3686 of 2012 in HRC No.7734-G of 2009 (Implementation of judgment of this Court, dated 30.3.2012 passed

${ }^{8}$ ShanzeyMinhal Mustafahttps://pakobserver.net/case-of-orange-line-metro-train/accessed 20/11/1

${ }^{9}$ orange line controversy Dawn newshttps://www.dawn.com/news/1345180 accessed 20/11/17

${ }^{10}$ Pakistan obseverhttps://pakobserver.net/case-of-orange-line-metro-train/ accessed 20/11/17
} 
'there had no power to entertain such litigation irrespective of authenticity and containing no necessary measures to rectify any genuine injury "alerting ' that prior to giving assistance to such litigant looking for relief , certain conditions must be fulfilled. ${ }^{1}$

\section{Conclution}

The current form of judiciary activism is not only dreadful for foreign investors, but for local investors as well. As far as CPEC is concerned Chinese investors would definitely ensure the favorable environment in the host state prior $r$ to launch their investment projects. There are many examples in the past which led to failure of investment projects, one such example is of Pakistan steel mill, due to judicial activism its privatization was ceased, another example is about a rental Power case where judicial activism was the cause of huge loss to the foreign investing company and the state had to face the issues in international courts. Orange Train case is the recent example of misuse of public interest rules on account of which its construction was put to hold leading to increase in its cost to billions. This makes it clear that if Pakistan's Government and Chinese company had decided its adequate routes without affecting the heritage sites and made a wise plan of action before its construction then there would be no interventions from the courts and no loss had to be faced in the proceedings of the case. When Supreme Court permitted to proceed its construction there had already been a huge expansion in the penalty and losses. In order to protect the investment in these situations, there is a section in the constitution of Pakistan, where the citizens in view of public interest rules, have given the power to file a petition inthe Supreme Court. However, in case if M.D Tahir v. Federation unnecessary litigation had been discouraged, highlighting the fact that unnecessary litigations and frivolous writ lead to wastage of precious time of court and hinder the court proceedings as well. In another case Khurram vs. Government of Punjab it was decided that frivolous writ should be discouraged. Though the above two cases were not against investors, but, such cases could be exemplified as right and instant decision by the courts in cases where protection was to be provided to the foreign investors. To protect the government from big losses the court would take immediate decisions. It is the utmost responsibility of the Government to build a strategy to provide a suitable environment to the investment projects in $\mathrm{CPEC}$, free of malpractices and corruption; and a proper legal framework should be designed at achieving this goal.

${ }^{1}$ M.D. Tahir v federation of Pakistan (1995) MLD 1864 